\title{
Deskripsi kemampuan representasi matematis ditinjau dari peminatan jenjang pendidikan menengah mahasiswa program studi pendidikan matematika pada mata kuliah statistika deskriptif
}

\section{Complaint Ability In Terms Of Mathematical Representation Of Peminatan Level of Education Secondary Mathematics Education Study Program Students On Courses Descriptive Statistics}

\author{
Reni Untarti ${ }^{{ }^{*}}$, Fitrianto Eko Subekti ${ }^{2}$ \\ ${ }^{12}$ Universitas Muhammadiyah Purwokerto \\ * Korespondensi Penulis. E-mail: reniuntarti@gmail.com,
}

Keywords:

Kualitatif

Kemampuan matematis

Purposive sampling

\begin{abstract}
Abstrak
Penelitian ini bertujuan untuk memperoleh gambaran kemampuan representasi matematis ditinjau dari peminatan saat jenjang pendidikan menengah mahasiswa semester I Program Studi Pendidikan Matematika FKIP Universitas Muhammadiyah Purwokerto. Jenis penelitian digunakan adalah penelitian deskriptif kualitatif. Prosedur penelitian ini meliputi tiga tahapan utama yaitu: tahap persiapan, tahap pelaksanaan, dan tahap analisis data. Pada tahap persiapan meliputi: (a) mempersiapkan soal tes kemampuan representasi matematis; (b) menentukan subyek penelitian, yaitu dengan cara purposive sampling, sehingga diperoleh 9 Mahasiswa, 3 mahasiswa dari jenjang SMA IPA, 3 mahasiswa dari jenjang SMA IPS, 3 mahasiswa dari jenjang SMK teknik untuk diwawancarai tentang kemampuan representasi matematisnya; dan (c) membuat pedoman wawancara. Tahap pelaksanaan meliputi: (a) mengambil data jenjang pendidikan menengah mahasiswa; (b) melaksanakan tes representasi matematis; dan (c) melaksanakan wawancara. Tahap analisis data meliputi: (a) tahapan reduksi data, (b) penyajian data, dan (c) penyimpulan data. Teknik pengumpulan data yang digunakan oleh peneliti melalui beberapa cara, yaitu: tes dan wawancara. Hasil penelitian menunjukkan bahwa: (a) mahasiswa dengan latar belakang SMA IPA mempunyai kemampuan representasi matematis, (b) mahasiswa dengan latar belakang SMA IPS belum memiliki kemampuan representasi matematis, dan (c) mahasiswa dengan latar belakang SMK sudah memiliki kemampuan representasi matematis, walaupun belum sempurna.
\end{abstract}


Keywords:

Qualitative

Mathematical ability

Purposive sampling

\begin{abstract}
This research aims to gain an overview of the capabilities of the mathematical representation of peminatan when the level of secondary education students semester Courses mathematics education FKIP Muhammadiyah University of Purwokerto. This type of research is a qualitative descriptive study is used. This research procedure includes three main stages: preparation phase, the phase of implementation, and the data analysis stage. At this stage of the preparation includes: (a) preparing mathematical representation ability test problem; (b) determine the subjects of research, namely by means of purposive sampling, so retrieved 9 students, 3 students from the HIGH SCHOOL level SCIENCE, 3 students from the HIGH SCHOOL level, IPS, 3 students of secondary VOCATIONAL SCHOOL of engineering to be interviewed about the ability of representation strings; and (c) make guidance interview. Stage of implementation include: (a) take data level of secondary education students; (b) carry out the mathematical representation of test; and (c) carry out the interview. The data analysis stage include the following: (a) the stage of data reduction, (b) the presentation of the data, and (c) a false assertion data. Data collection techniques used by researchers in several ways, namely: tests and interviews. The results showed that: (a) a student with a background in HIGH SCHOOL mathematical representation of IPA has the ability, (b) HIGH SCHOOL student with a background of IPS does not yet have the capability of mathematical representation, and (c) a student with background CMS already has the ability of mathematical representation, though not yet perfect.
\end{abstract}

Copyright (C) 2018 Universitas Mercu Buana Yogyakarta. All rights reserved.

\title{
PENDAHULUAN
}

Mahasiswa Pendidikan Matematika, Universitas Muhammadiyah Purwokerto (UMP) merupakan mahasiswa yang dididik dan dilatih untuk dipersiapkan menjadi calon guru yang profesional di Sekolah Menengah, baik SMP maupun SMA. Untuk itu, mereka dibekali dengan berbagai materi matematika yang menjadi dasar untuk mengajar matematika di sekolah menengah. Salah satu mata kuliah wajib yang harus diambil pada semester I adalah mata kuliah statistika deskriptif.

Mata kuliah statistika deskriptif bertujuan mempersiapkan mahasiswa untuk memahami materi statistika serta bagaimana membelajarkannya di sekolah menengah. Mata kuliah ini merupakan pengembangan materi statistika pada jenjang pendidikan menengah baik pendidikan menengah umum maupun kejuruan, sehingga mata kuliah ini menjadi mata kuliah dasar yang harus dikuasai oleh mahasiswa program studi pendidikan matematika. Salah satu kemampuan matematis yang harus dimiliki mahasiswa agar kompetensi mata kuliah tersebut tercapai adalah kemampuan representasi matematis. Kemampuan representasi matematis menjadikan mahasiswa tidak hanya mampu menggunakan rumus dalam menyelesaikan masalah(Pawestri \& Sukoco, 2017)(Widyastuti \& Nurhamida, 2017). Apabila hal ini terjadi, maka menjadikan materi pembelajaran kurang bermakna.

Untuk membuat materi dalam statistika deskriptif bermakna, diperlukan berbagai kemampuan matematis, salah satunya adalah kemampuan representasi matematis(Reahanah, 2016). Kemampuan representasi matematis merupakan salah satu kemampuan yang harus dimiliki oleh siswa dalam pembelajaran matematika dan menjadi dasar bagaimana seseorang dapat memahami dan menggunakan ide mereka dalam bentuk diagram, tampilan grafik, maupun symbol (Tipps, Johnson, \& Kennedy, 2011). Ada empat ide digunakan untuk memahami konsep representasi, yaitu: (1) representasi dapat dipandang sebagai abstraksi internal dari ide-ide matematika atau

Reni untarti et.all (Deskripsi kemampuan representasi matematis ditinjau dari peminatan jenjang pendidikan menengah mahasiswa program studi pendidikan matematika pada mata kuliah statistika deskriptif) 
skemata kognitif yang dibangun oleh mahasiswa melalui pengalaman; (2) representasi dipandang sebagai reproduksi mental dari keadaan sebelumnya; (3) representasi dipandang sebagai sajian secara struktur melalui gambar, simbol ataupun lambang; dan (4) representasi dipandang sebagai pengetahuan tentang sesuatu yang mewakili sesuatu yang lain(Luitel, 2002).

Representasi yang digunakan dalam pendidikan matematika kedalam lima jenis, yaitu meliputi representasi objek dunia nyata, representasi konkret, representasi simbol aritmetika, representasi bahasa lisan atau verbal dan representasi gambar atau grafik(Nurrakhmi \& Lukito, 2014). Di antara kelima representasi tersebut, tiga yang terakhir lebih abstrak dan merupakan tingkat representasi yang lebih tinggi dalam memecahkan masalah matematika(Hwang, Chen, Dung, Educational, \& 2007, 2007). Kemampuan representasi bahasa atau verbal adalah kemampuan menerjemahkan sifat-sifat yang diselidiki dan hubungannya dalam masalah matematika ke dalam representasi verbal atau bahasa. Kemampuan representasi gambar atau grafik adalah kemampuan menerjemahkan masalah matematis ke dalam gambar atau grafik, sedangkan kemampuan representasi simbol aritmetika adalah kemampuan menerjemahkan masalah matematika ke dalam representasi rumus aritmatika.

Dalam penelitian ini, indikator kemampuan representasi matematis meliputi: kemampuan untuk menyajikan data atau informasi dari masalah matematis ke dalam bentuk diagram, grafik atau tabel atau sebaliknya; (b) kemampuan menggunakan simbol matematis dengan tepat dalam penyelesaian masalah matematis; dan (c) kemampuan menuliskan pendapat atau alasan dengan tepat.

Walaupun kemampuan representasi matematis merupakan kemampuan yang penting dalam pembelajaran matematika, akan tetapi kemampuan representasi matematis siswa Indonesia masih rendah terutama pada representasi visual. Rendahnya kemampuan representasi visual siswa di Indonesia dapat dilihat dari laporan Programme for International Student Assesment (PISA,) tahun 2009 dan Trends in International Mathematics and Science Study (TIMSS) tahun 2011. Pada PISA tahun 2009 yang diikuti oleh 65 negara, Indonesia menduduki peringkat ke 61 dengan skor ratarata yang diperoleh dalam matematika sebesar 371 poin. Selain itu, hasil TIMSS tahun 2011 yang diikuti oleh 45 negara menunjukkan bahwa Indonesia menduduki peringkat ke 38 dengan skor ratarata yang diperoleh dalam matematika sebesar 386 poin dan rata-rata persentase siswa menjawab benar pada dimensi kognitif yaitu penerapan adalah sebesar $23 \%$.

Berdasarkan hasil observasi dalam pembelajaran statistika deskriptif, ditemukan beberapa permasalahan, meliputi: (1) mahasiswa mampu menyajikan data, tetapi mereka tidak tahu tujuan mengapa data tersebut disajikan dalam salah satu diagram; (2) mahasiswa mampu mencari mean, median, modus, quartil, desil, dan persentil, tetapi mereka tidak paham apa tujuan mereka mencari nilai-nilai tersebut. Hal-hal tersebut dapat diduga merupakan permasalahan yang berkaitan dengan kemampuan representasi matematis. Dengan ketidaktepatan dalam menyajikan suatu masalah dalam bentuk diagram berakibat ketidaktepatan informasi yang didapat dari diagram tersebut. Selain itu, dengan ketidaktahuan mereka tentang arti mean, median, modus, quartil, desil dan persentil menjadikan materi tersebut kurang bermakna..

Berdasarkan deskripsi di atas, maka tujuan dari penelitian ini adalah untuk memperoleh gambaran kemampuan representasi matematis ditinjau dari peminatan saat jenjang pendidikan menengah mahasiswa semester I Program Studi Pendidikan Matematika FKIP Universitas Muhammadiyah Purwokerto.

\section{METODE.}

Jenis penelitian yang dilakukan peneliti adalah penelitian kualitatif. Adapun metode yang digunakan dalam penelitian menggunakan metode penelitian deskriptif dengan pendekatan kualitatif. Karena peneliti ingin memberikan gambaran yang lebih mendalam mengenai 
Vol. 2, No. 2, April 2018, pp. 15-32

kemampuan representasi matematis ditinjau dari jenjang pendidikan sekolah menengah mahasiswa semester I Pendidikan Matematika FKIP Universitas Muhammadiyah Purwokerto.

Penelitian ini dilakukan terhadap mahasiswa Program Studi Pendidikan Matematika Semester I Universitas Muhammadiyah Purwokerto yang mengambil mata kuliah statistika deskriptif. Pelaksanaan penelitian dimulai pada pertengahan bulan November 2016 sampai dengan pertengahan bulan Februari tahun 2017.

Prosedur penelitian ini meliputi tiga tahapan utama yaitu: tahap persiapan, tahap pelaksanaan, dan tahap analisis data. Pada tahap persiapan meliputi: (a) mempersiapkan soal yang mengukur kemampuan representasi matematis; (b) menentukan subyek penelitian, yaitu dengan cara purposive sampling, sehingga diperoleh 9 Mahasiswa, 3 mahasiswa dari jenjang SMA IPA, 3 mahasiswa dari jenjang SMA IPS, 3 mahasiswa dari jenjang SMK teknik untuk diwawancarai tentang kemampuan representasi matematisnya; dan (c) membuat pedoman wawancara. Tahap pelaksanaan meliputi: (a) mengambil data jenjang pendidikan menengah mahasiswa; (b) melaksanakan tes representasi matematis; dan (c) melaksanakan wawancara. Tahap analisis data meliputi: (a) tahapan reduksi data, (b) penyajian data, dan (c) penyimpulan data. Teknik pengumpulan data yang digunakan oleh peneliti melalui beberapa cara, yaitu: tes, dan wawancara.

\section{HASIL DAN PEMBAHASAN}

Sampel dalam penelitian ini diberi simbol IPA untuk mahasiswa yang mengambil SMA IPA saat sekolah menengah, IPS untuk mahasiswa yang mengambil peminatan SMA IPS, dan SMK untuk mahasiswa yang mengambil SMK Teknik. Jadi, IPA1, IPA2, dan IPA3 digunakan untuk menyimbolkan secara berturut-turut mahasiswa 1, 2, dan 3 yang mengambil jurusan SMA IPA. Begitu juga bagi mahasiswa yang mengambil peminatan SMA IPS dan SMK.

1. Kemampuan untuk menyajikan data atau informasi dari masalah matematis ke dalam bentuk diagram, grafik atau tabel atau sebaliknya.

Indikator kemampuan representasi matematis ini diukur pada soal yang meminta mahasiswa untuk menyajikan kembali data penjualan sepeda motor dari tahun 2005 sampai 2015 dalam bentuk tabel ke dalam bentuk diagram yang sesuai.

a. IPA

Hasil pekerjaan IPA1, IPA2, dan IPA3 berturut dapat dilihat pada gambar 1, 2, dan 3 di bawah ini.

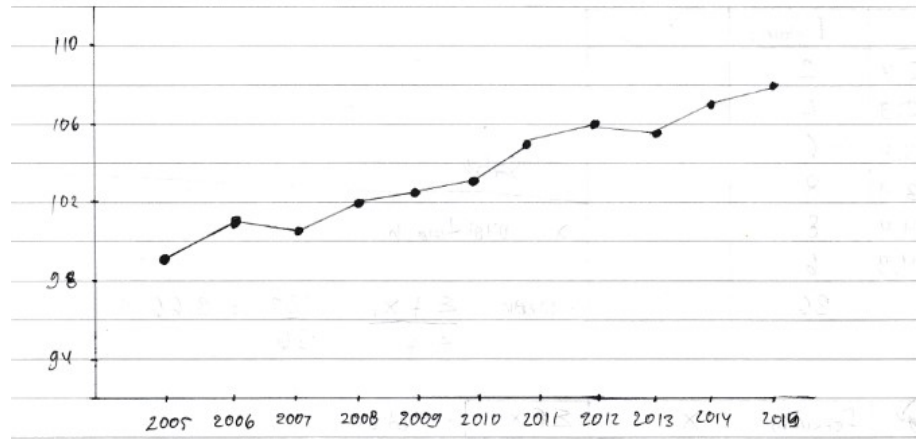

Gambar 1 Pekerjaan IPA1 Indikator 1 

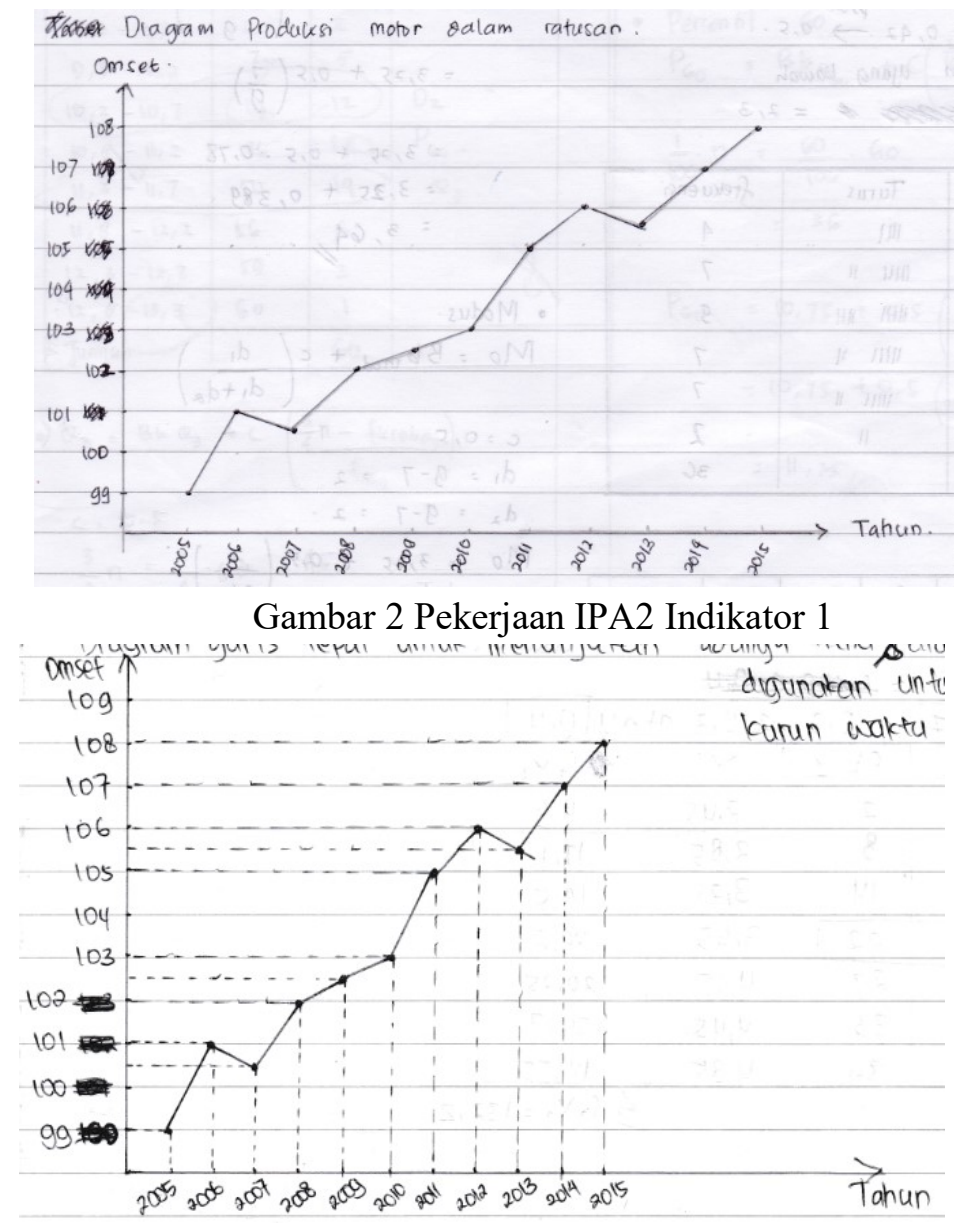

Gambar 3 Pekerjaan IPA2 Indikator 1

Berdasarkan gambar 1, 2, dan 3 dapat dilihat bahwa IPA1, IPA2, dan IPA3 sudah dapat menyajikan data tentang penjualan sepeda motor dalam diagram yang tepat, yaitu diagram garis. Akan tetapi, jika diperhatikan lebih cermat baik IPA1, IPA2, dan IPA3 tidak lengkap dalam menyajikannya. Ketidaklengkapan tersebut meliputi: (a) IPA1 tidak memberikan judul pada diagram yang digambar, tidak memberikan keterangan pada sumbu horisontal yang menyatakan tahun penjualan dan sumbu vertikal yang menyatakan banyaknya sepeda motor yang terjual, tidak memberikan keterangan tentang banyaknya motor yang dijual dalam bentuk ratusan, dan tidak memberikan garis penghubung ke sumbu vertikal dan horizontal; (b) IPA2 tidak memberikan garis penghubung ke sumbu vertikal dan horisonsal, sehingga informasi yang disajikan kurang jelas; dan (c) IPA3 tidak menuliskan judul diagram yang digambar dan walaupun IPA3 sudah menggambarkan garis yang menghubungkan dengan sumbu vertikal dan horisontal, ia tidak menuliskan nilainya dengan tepat, terutama jika nilainya adalah bilangan desimal.

Saat wawancara IPA1, IPA2, dan IPA3 dapat menunjukkan kekurangan-kekurangan diagram garis yang digambarnya. Hal ini menunjukkan bahwa sebenarnya IPA1, IPA2, dan IPA3 dapat memahami cara menyajikan gambar dalam diagram, khususnya diagram garis, dengan tepat. Akan tetapi, mereka ternyata terburu-buru saat menyelesaikan soal tersebut, sehingga tidak teliti dalam dan tidak lengkap dalam menyajikan data penjualan sepeda motor dari tahun 2005 sampai tahun 2015 dalam bentuk diagram garis.

b. IPS

Hasil pekerjaan IPS1, IPS2, dan IPS3 disajikan pada gambar 4, 5, dan 6 berikut. 
Vol. 2, No. 2, April 2018, pp. 15-32

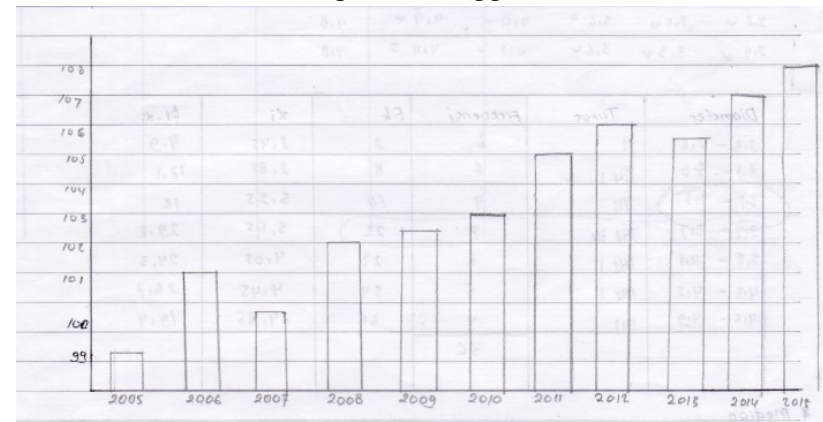

Gambar 4 Pekerjaan IPS1 Indikator 1

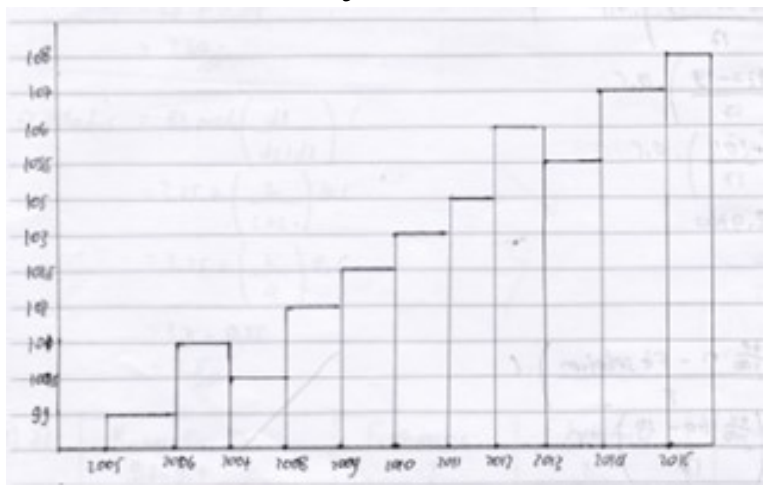

Gambar 5 Pekerjaan IPS2 Indikator 1

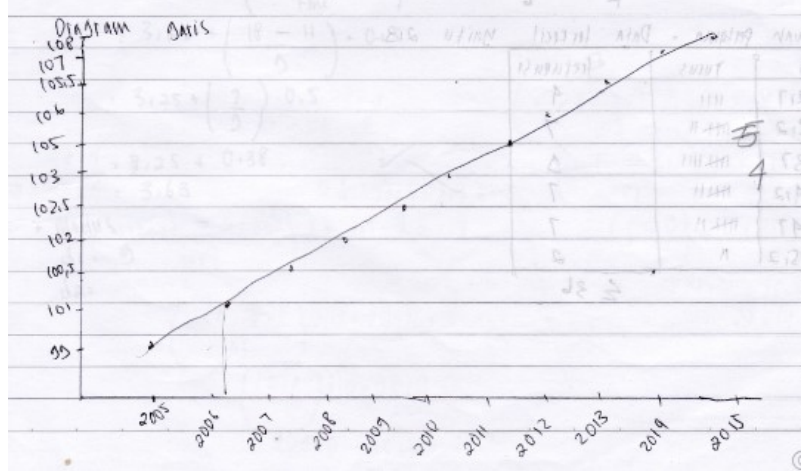

Gambar 6 Pekerjaan IPS3 Indikator 1

Berdasarkan gambar 4, 5, dan 6 terlihat bahwa IPS1, IPS2, dan IPS3 salah dalam menyajikan kembali data tentang penjualan sepeda motor dari tahun 2005 sampai 2015. IPS1 dan IPS2 menyajikan kembali data tersebut dalam diagram batang, sedangkan IPS3 walaupun terlihat seperti diagram garis, tetapi itu tidak tepat. Selain itu, IPS1 dan IPS2 tidak memberikan judul diagram, tidak memberikan keterangan pada sumbu vertikal dan horisontal, sedangkan IPS3 tidak memberikan judul pada diagram yang sudah dibentuk. Hasil tes di atas dikuatkan dengan hasil wawancara. Berdasarkan hasil wawancara IPS1, IPS2, dan IPS3 memang tidak memahami perbedaan penggunaan diagram garis dan diagram batang. IPS1, IPS2, dan IPS3 hanya menghafalkan contoh soal yang diberikan oleh dosen.

c. SMK

Pekerjaan SMK1, SMK2, dan SMK3 yang mengukur indikator ini dapat dilihat secara berturut-turut pada gambar 7, 8, dan 9 di bawah ini. menengah mahasiswa program studi pendidikan matematika pada mata kuliah statistika deskriptif) 


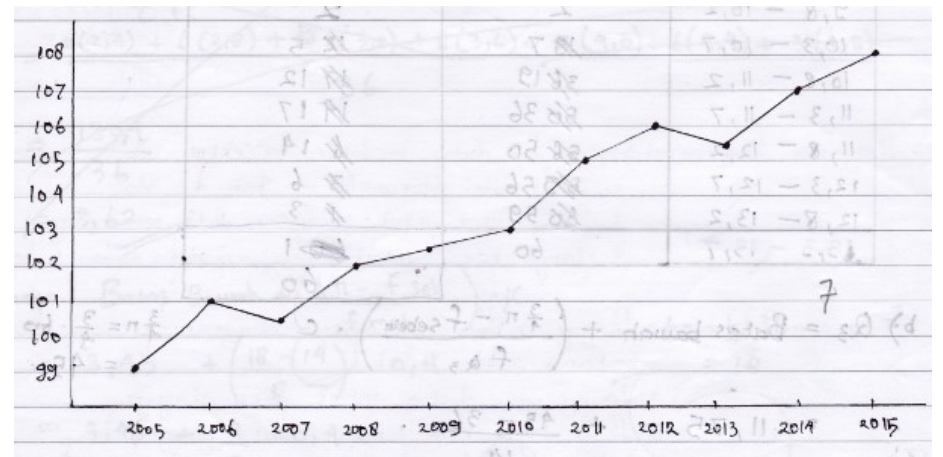

Gambar 7 Pekerjaan SMK1 Indikator 1

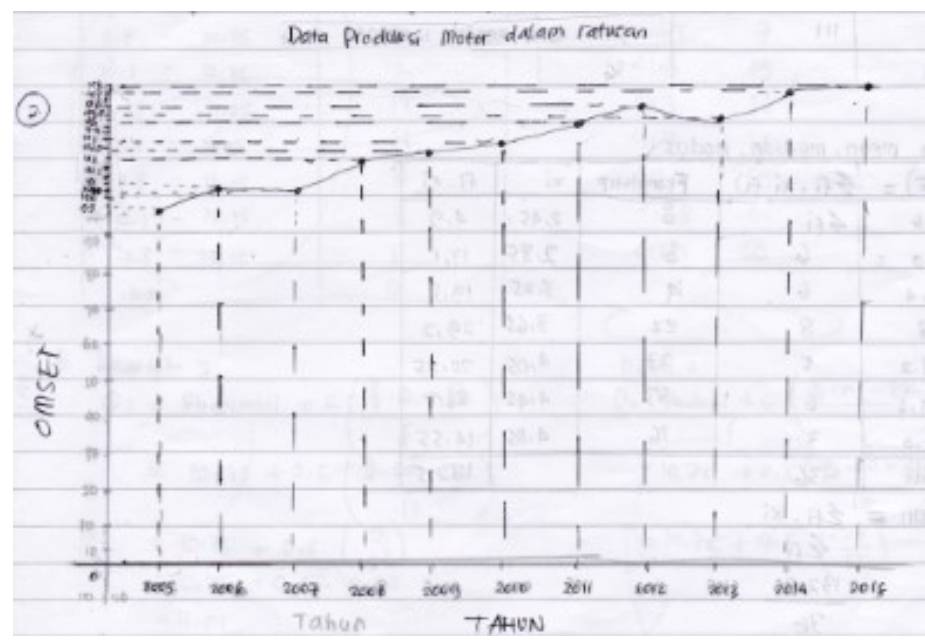

Gambar 8 Pekerjaan SMK2 Indikator 1

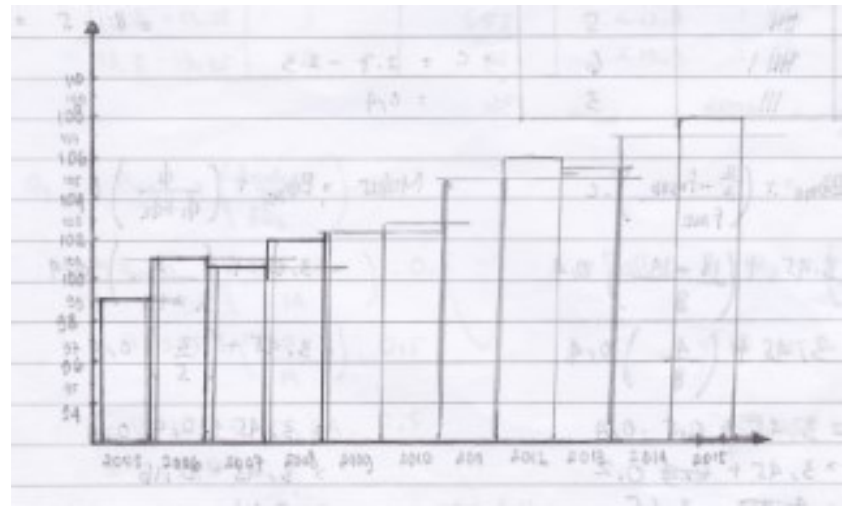

Gambar 9 Pekerjaan SMK3 Indikator 1

Pada gambar di atas, dapat dilihat bahwa SMK1 dan SMK2 dapat menyajikan kembali informasi pada soal, dengan tepat, yaitu menggunakan diagram garis. SMK1 dan SMK2 tidak memberikan judul pada diagram tersebut, SMK1 tidak memberikan keterangan pada sumbu vertikal dan horisontal, sedangkan SMK2 sudah memberikannya. SMK3 tidak tepat dalam menyajikan kembali informasi yang diinginkan, karena SMK3 menggambar diagram batang. Hasil wawancara diketahui bahwa SMK1 dan SMK2 bisa menyajikan kembali data yang ada pada soal dengan tepat. Selain itu, berdasarkan hasil wawancara diketahui bahwa sebenarnya SMK3 tidak yakin apakah diagram batang yang dibuatnya sudah tepat atau belum. Ketika diminta untuk mengkomunikasikan kembali diagram batang yang disusunnya, SMK3 menyadari bahwa diagram tersebut tidak memberikan informasi apapun kepada orang lain. 
Vol. 2, No. 2, April 2018, pp. 15-32

2. Kemampuan menggunakan simbol matematis dengan tepat dalam penyelesaian masalah matematis.

Hasil pekerjaan mahasiswa terkait dengan indikator ini sebagai berikut.

a. IPA

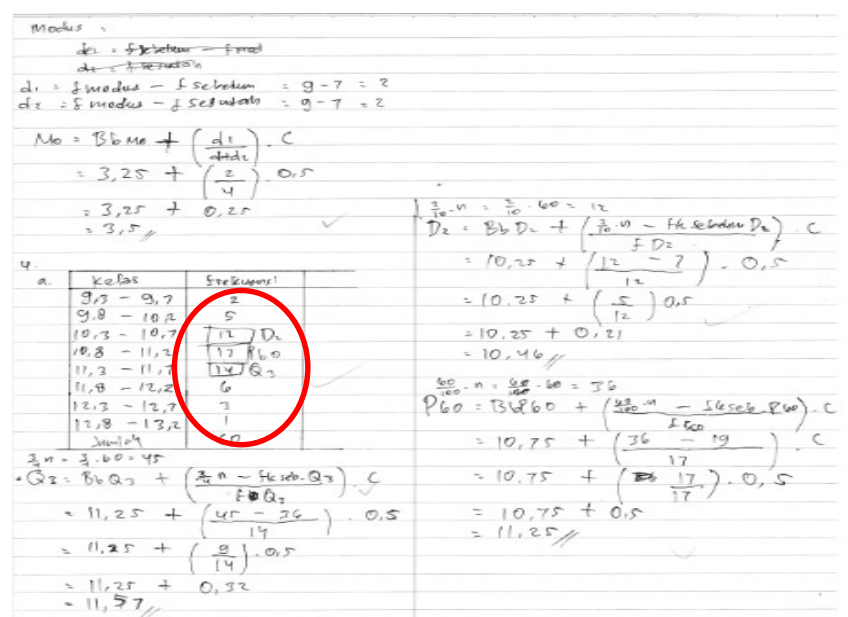

Gambar 10 Pekerjaan IPA1 Indikator 2

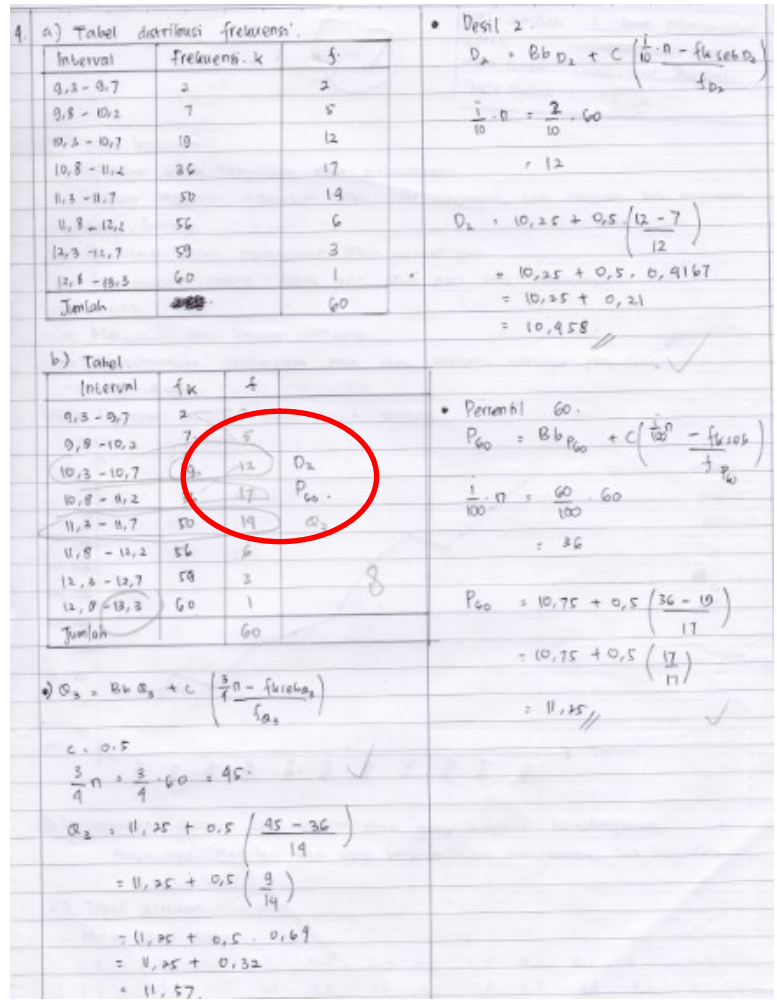

Gambar 11 Pekerjaan IPA2 Indikator 2 menengah mahasiswa program studi pendidikan matematika pada mata kuliah statistika deskriptif) 


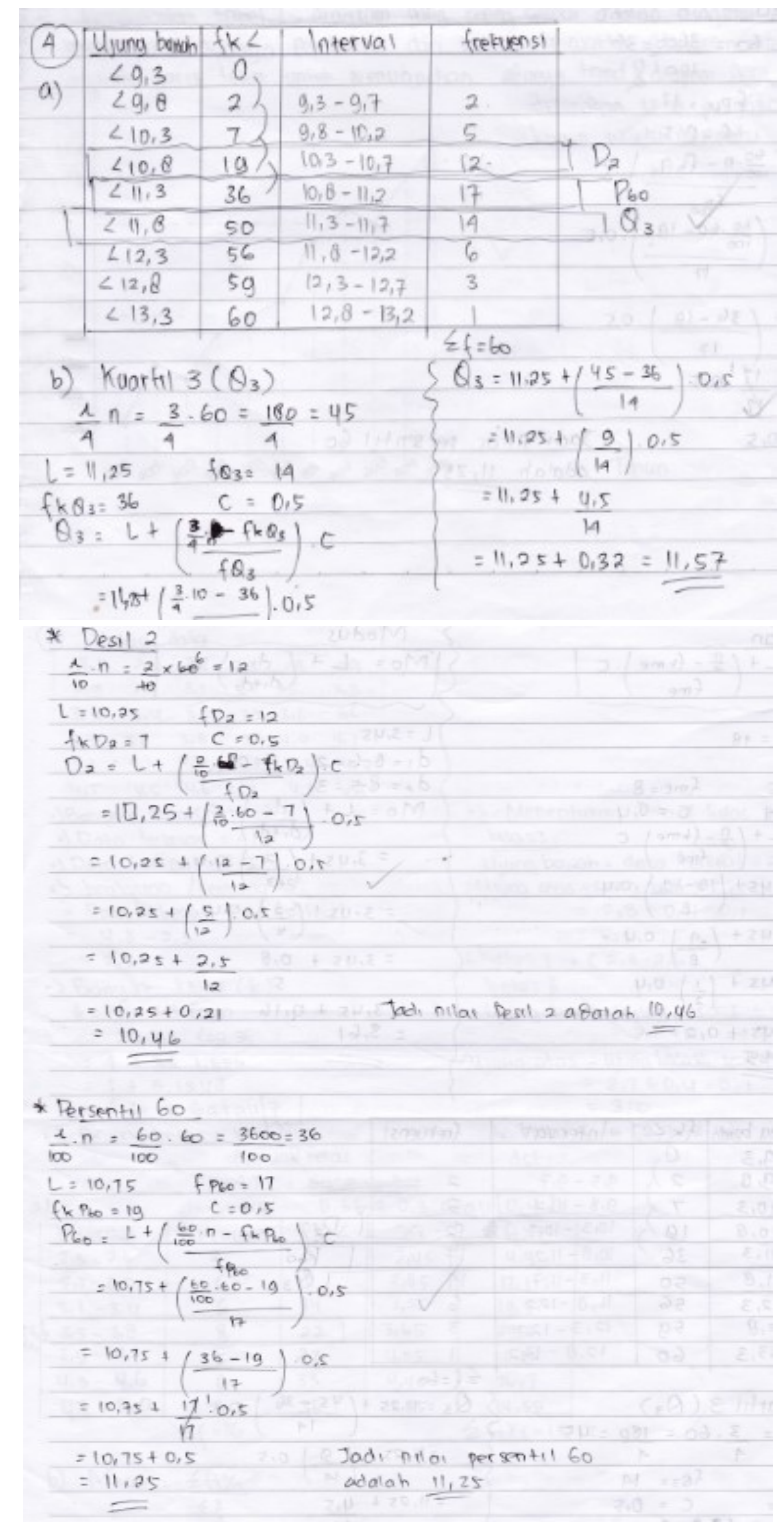

Gambar 12 Pekerjaan IPA3 Indikator 2

Berdasarkan gambar 10, 11, dan 12 di atas, diketahui bahwa IPA1, IPA2, dan IPA3 sudah tepat dalam menggunakan simbol-simbol matematis saat menyelesaikan masalah tentang menentukan kuartil, desil, dan persentil. IPA1, IPA2, dan IPA3 menggunakan simbol $Q_{3}$ untuk kuartil ke-3, $D_{2}$ untuk desil ke-2, $P_{60}$ untuk persentil ke-60, $B b Q_{3}$ untuk batas bawah kelas kuartil ke-3, $B b D_{2}$ untuk batas bawah kelas desil ke-2, $B b P_{60}$ untuk batas bawah kelas persentil ke-60, $f_{k}$ untuk frekuensi kumulatif, dan $n$ banyaknya data. Simbolsimbol tersebut merupakan simbol-simbol yang biasa digunakan dalam matematika, terutama untuk materi pembelajaran statistika. Selain itu, IPA1, IPA2, dan IPA3 juga memberikan keterangan pada tabel di mana letak $Q_{3}, D_{2}$, dan $P_{60}$. Dengan pemberian keterangan ini akan mempermudah dalam menemukan di mana letak data $Q_{3}, D_{2}$, dan $P_{60}$. 
b. IPS

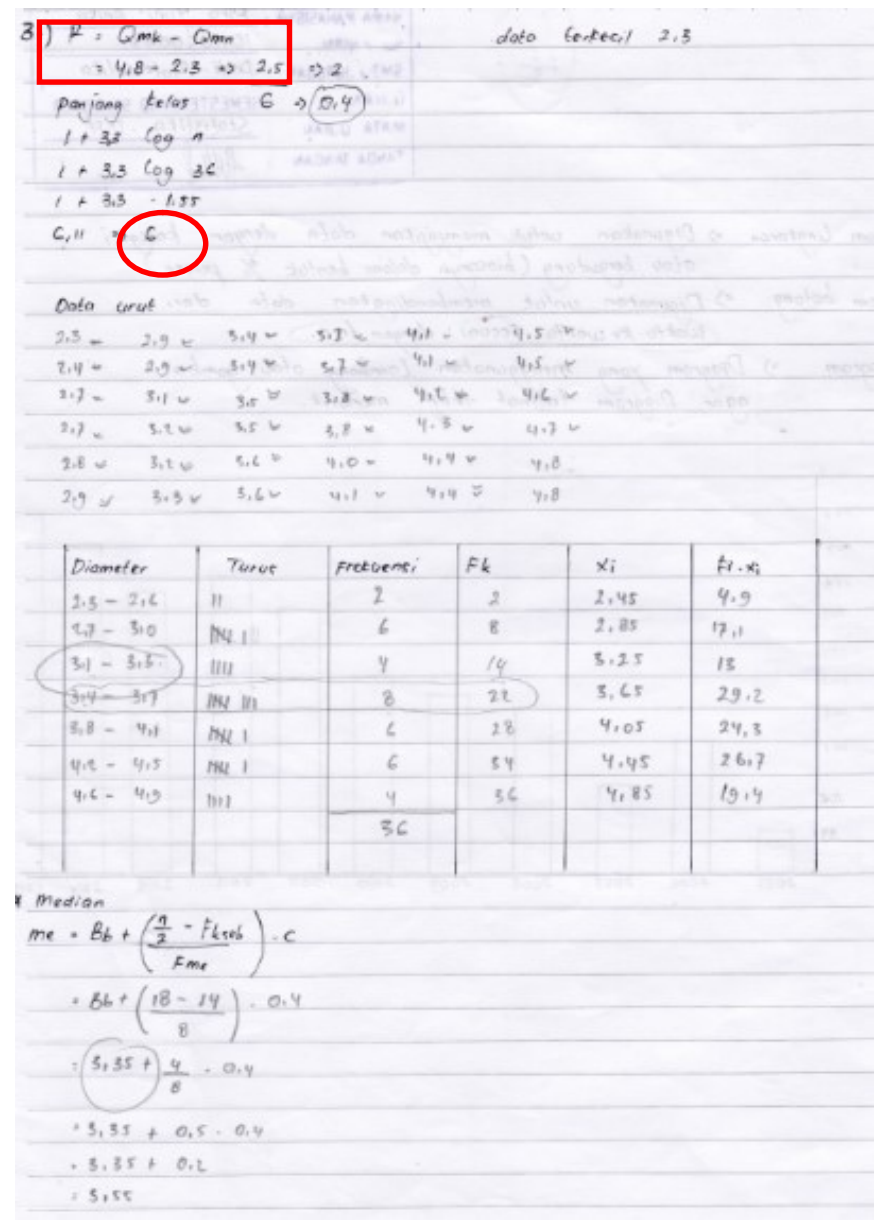

Gambar 13 Pekerjaan IPS1 Indikator 2

Gambar 13 di atas menunjukkan bahwa IPS1 kurang tepat dan kurang lengkap dalam menggunakan simbol matematis untuk menyelesaikan masalah yang terkait dengan menyusun tabel distribusi frekuensi data berkelompok dan menentukan mediannya. Contoh: ketika IPS1 menggunakan simbol $R$ untuk menyatakan range atau jangkauan tanpa memberikan keterangan terlebih dahulu. Hal ini dikarenakan simbol $R$ bukan simbol baku dalam matematika. Simbol $R$ dapat menyatakan jari-jari, range, dll. Selain itu, saat IPS1 menuliskan rumus $R=Q_{\text {mak }}-Q_{\min }$, ia menggunakan simbol $Q_{m a k}$ dan $Q_{\min }$ untuk menyimbolkan data yang terbesar dan terkecil, padahal simbol $Q$ biasanya digunakan untuk menyimbolkan kuartil.

Pada saat IPS1 menentukan panjang kelas, ia juga tidak memberikan simbol "=" pada setiap langkah penyelesaiannya. Hal ini mengakibatkan secara matematis tidak ada hubungan pada setiap langkahnya. Saat menentukan median, IPS1 menggunakan simbol $B b$ untuk menunjukkan batas bawah. Walaupun itu sudah benar dan sudah menunjukkan yang dimaksud adalah batas bawah kelas median, akan lebih lengkap apabila dituliskan dengan $B b_{m e}$. Selain itu, IPS1 juga tidak tepat dalam menggunakan tanda “ $\Rightarrow$ ”. IPS1 menggunakan tanda tersebut untuk menyimbolkan "mendekati" pada saat menentukan panjang kelas, yang mana berdasarkan hasil perhitungan diperoleh panjang kelasnya adalah 6,11 . Hal ini tidak mungkin, karena panjang kelas tidak mungkin dinyatakan dalam bilangan desimal, sehingga harus dibulatkan dalam bilangan bulat terdekat, yaitu 6 . Seharusnya, IPS1 
menggunakan tanda " $\approx$ " untuk menyimbolkan "mendekati", sehingga penulisan yang tepat adalah "panjang kelas $=6,11 \approx 6$ ". Dalam matematika, simbol " $\Rightarrow$ " adalah simbol baku untuk menyatakan implikasi dalam logika matematika.

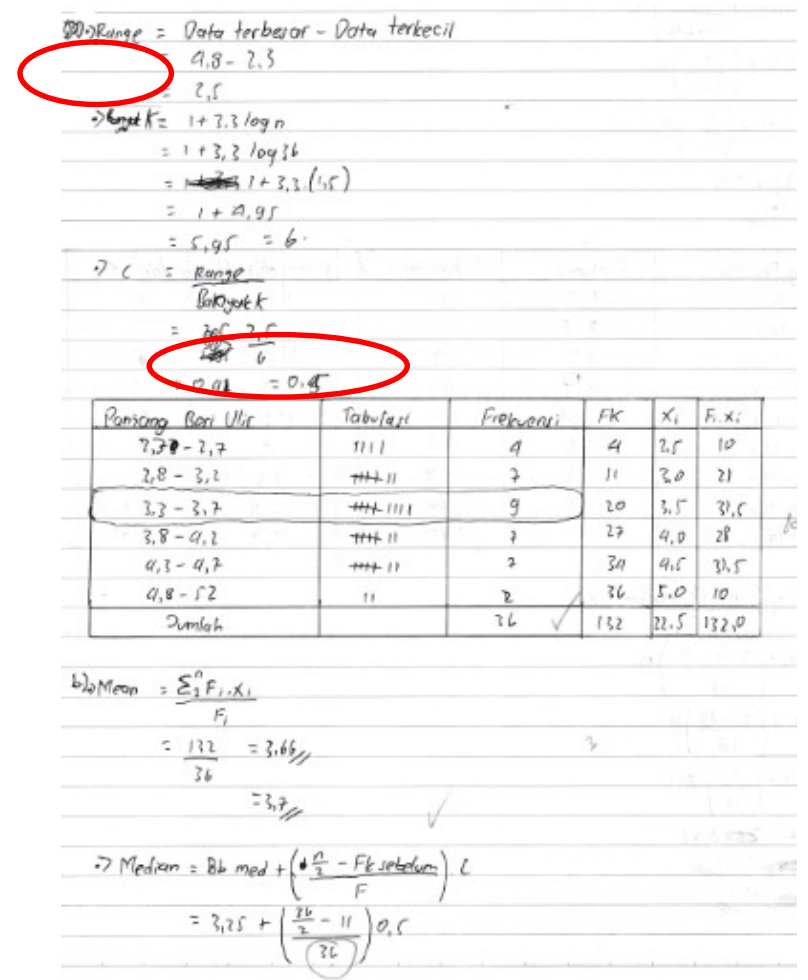

Gambar 14 Pekerjaan IPS2 Indikator 2

Pada gambar 14 di atas, terlihat bahwa IPS2 tidak memberikan keterangan bahwa simbol $K$ menyatakan kelas. Hal ini menunjukkan bahwa IPS2 kurang lengkap dalam menyajikan simbol-simbol matematis. Selain itu, IPS2 menggunakan tanda "=" untuk menyimbolkan "mendekati" yang seharusnya menggunakan tanda " $\approx$ ". Hal ini terlihat pada saat menentukan banyaknya kelas. IPS2 menuliskan " 5,95 =6", seharusnya " 5,95 $\approx 6$ ".

Berdasarkan gambar 15 di bawah ini, diketahui bahwa IPS3 tidak lengkap dalam menuliskan simbol matematis. IPS3 memberikan keterangan pada tabel yang telah di buat. Harusnya IPS3 menuliskan keterangan "data" dan "frekuensi kumulatif" pada tabel distribusi frekuensi yang telah disusun.

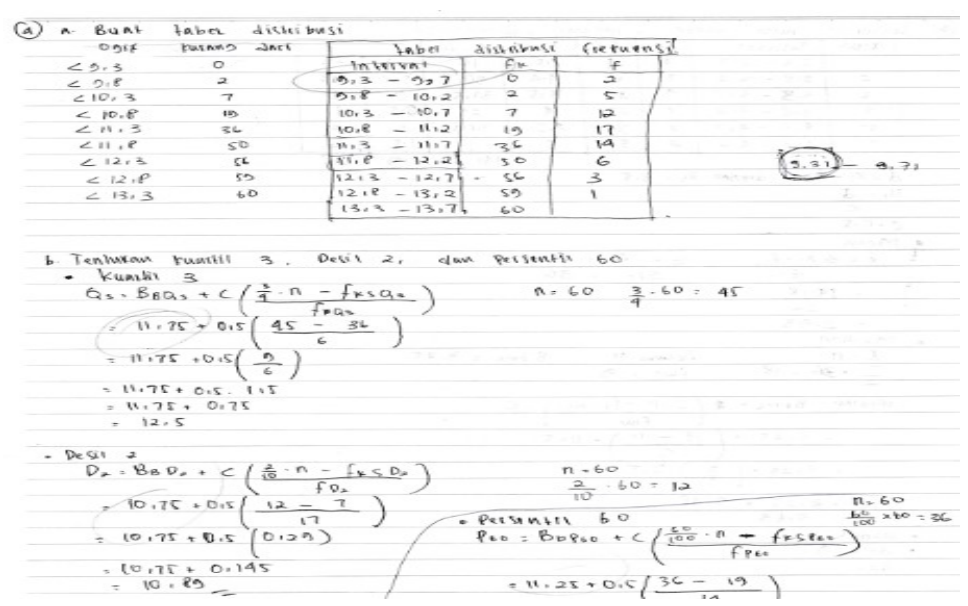

Gambar 15 Pekerjaan IPS3 Indikator 2 
c. SMK

Berdasarkan gambar 16 di bawah ini, diketahui bahwa SMK1 secara umum sudah tepat dalam menggunakan simbol-simbol matematis, walaupun ada satu simbol yang kurang lengkap. Simbol yang dimaksud adalah ketika SMK1 menuliskan “ $f_{\text {sebelum }}$ " untuk menyatakan frekuensi kumulatif kelas sebelum", seharusnya disimbolkan dengan " $f k_{\text {sebelum }}$ ". Selain itu, SMK1 menggunakan simbol $Q_{3}, D_{2}, P_{60}$, dan $n$ untuk menyimbolkan secara berturut-turut kuartil ke-3, desil ke-2, persentil ke-60, dan banyaknya data.

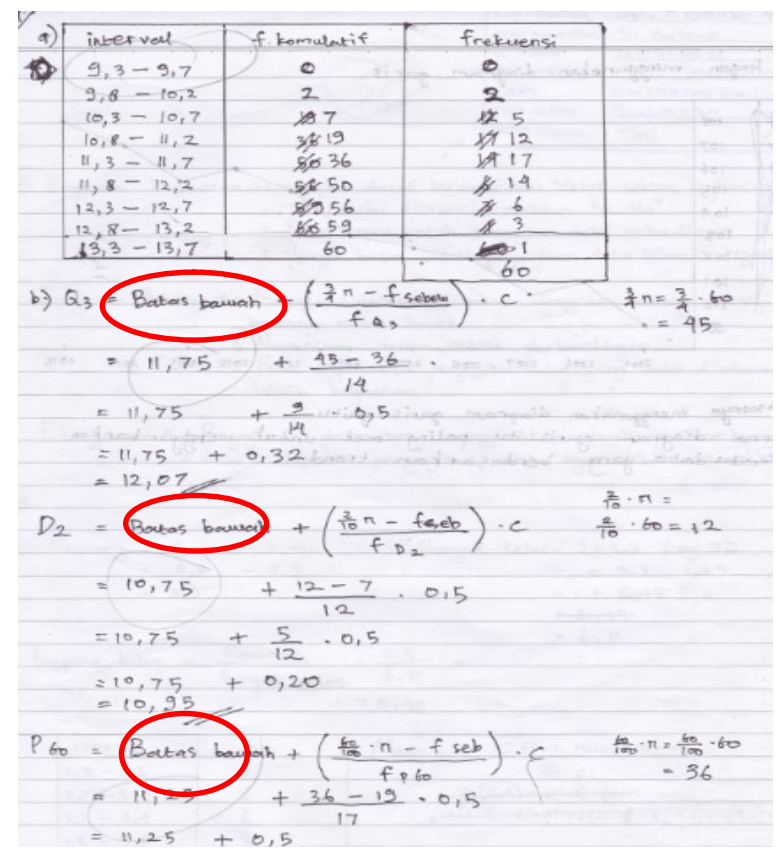

Gambar 16 Pekerjaan SMK1 Indikator 2

Berdasarkan gambar 17 di bawah ini, terlihat bahwa SMK2 secara umum sudah mampu menggunakan simbol matematis dengan tepat, akan tetapi belum sempurna. Misalnya, ketika SMK2 ingin menyimbolkan tentang frekuensi kumulatif kelas sebelumnya, SMK2 hanya menuliskan simbol " $f k$ ", seharusnya SMK2 menuliskan " $f k_{\text {sebelum }}$ ", karena symbol " $f k$ " hanya untuk menyimbolkan frekuensi kumulatif.

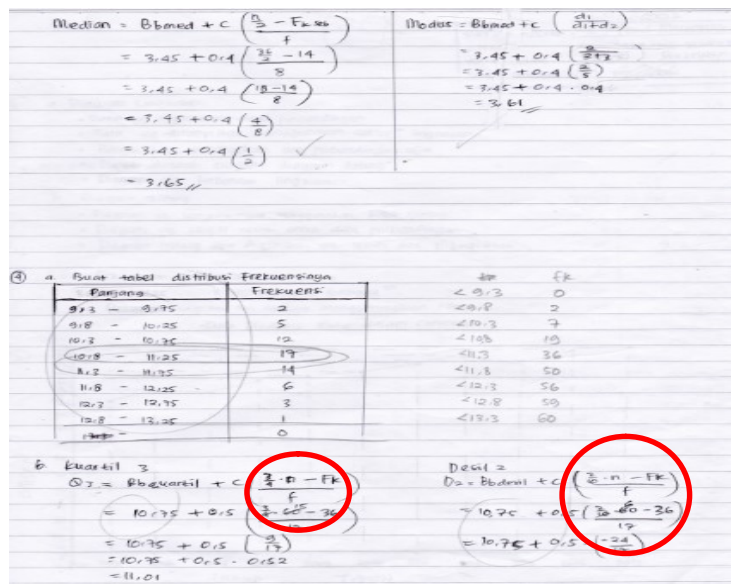

Gambar 17 Pekerjaan SMK2 Indikator 2 menengah mahasiswa program studi pendidikan matematika pada mata kuliah statistika deskriptif) 
Berdasrkan hasil pekerjaan SMK3 seperti pada gambar 18 di bawah ini, terlihat bahwa SMK3 sudah tepat dalam menggunakan simbol matematis saat menyelesaikan masalah. Hanya saja SMK3 kurang teliti dalam menggunkan simbol " $r$ " untuk menyatakan "range" tanpa memberikan keterangan sebelumnya. Hal ini tidak tepat karena simbol " $r$ " dalam matematika merupakan simbol baku untuk menyatakan jari-jari suatu lingkaran.

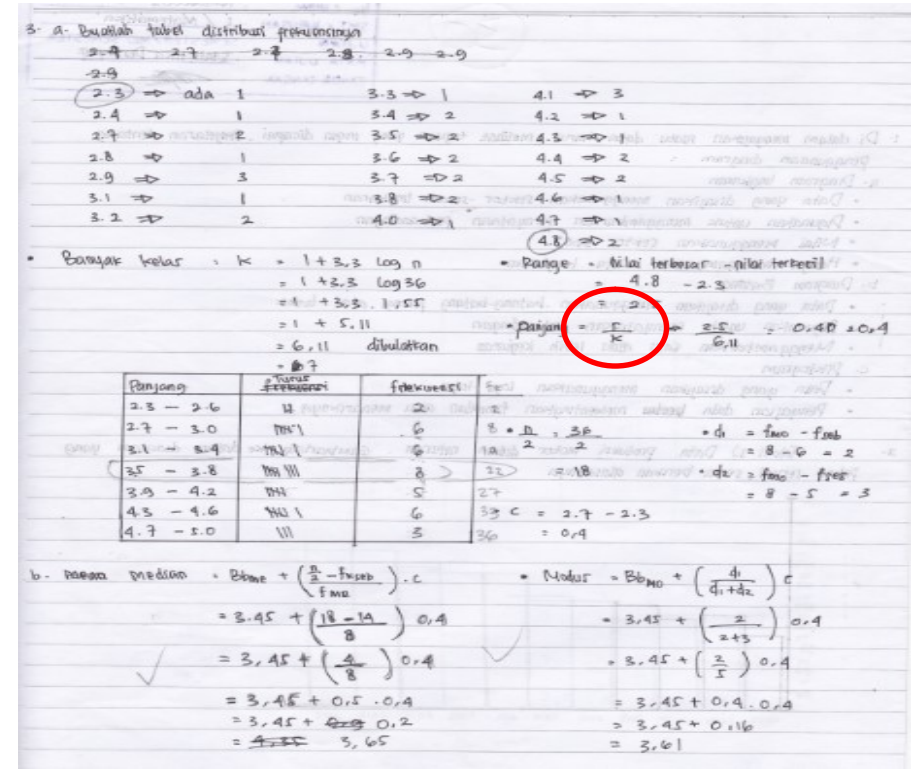

Gambar 18 Pekerjaan SMK3 Indikator 2

3. Menyampaikan pendapat atau alasan dengan tepat.

Kemampuan ini menuntut mahasiswa agar mampu berargumen secara tertulis terkait keputusan atau langkah yang telah dipilih untuk menyelesaikan masalah yang ada. Masalah yang dimunculkan dosen untuk mengukur kemampuan ini adalah mahasiswa diminaa untuk memberikan alasan yang tepat saat memilih diagram untuk menyajikan kembali data penjualan sepeda motor dari tahun 2005 sampai 2015 dalam diagram yang sesuai (diagramnya disajikan dalam indikator 1). Hasil pekerjaan mahasiswa sebagai berikut.

a. IPA

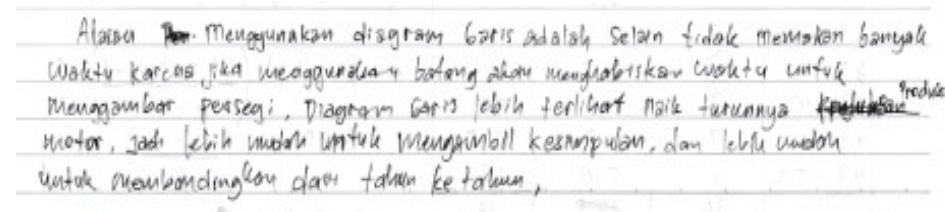

Gambar Pekerjaan IPA1 Indikator 3

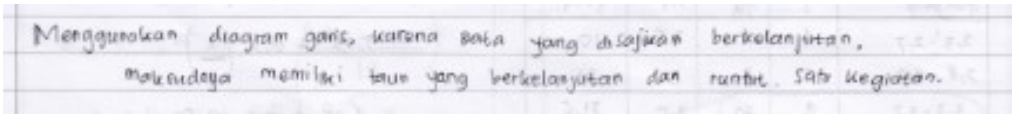

Gambar 20 Pekerjaan IPA2 Indikator 3

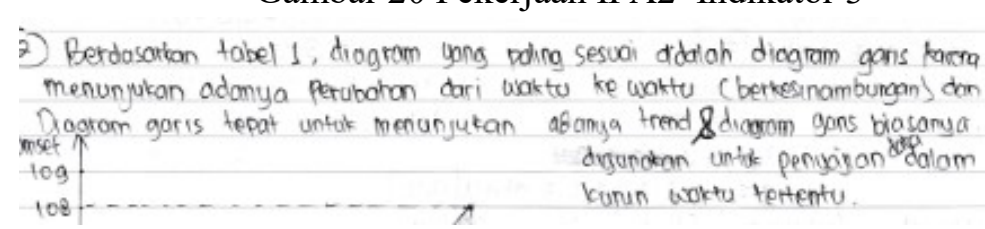

Gambar 21 Pekerjaan IPA3 Indikator 3

Berdasarkan gambar 19, 20, dan 21 di atas, alasan mengapa IPA1, IPA2, dan IPA3 menggunakan diagram garis adalah karena menunjukkan adanya perubahan dari waktu ke 
Vol. 2, No. 2, April 2018, pp. 15-32

waktu (berkesinambungan). Selain itu, dengan diagram garis dapat menunjukkan adanya trend dalam waktu tertentu. Alasan yang disampaikan oleh IPA3 tersebut sudah sesuai dan tepat.

b. IPS

IPS1 tidak menuliskan alasan mengapa menyajikan data penjualan sepeda motor dalam diagram batang. Selain tidak memberikan alasan, diagram yang digambar IPS1 juga tidak tepat. IPS1 menggambar diagram batang, padahal seharusnya diagram garis.

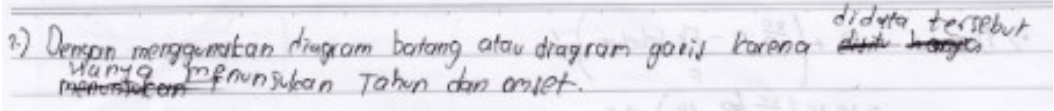

Gambar 22 Pekerjaan IPS2 Indikator 3

IPS2 tidak memberikan jawaban yang tegas diagram yang sesuai untuk menyajikan data penjualan sepeda motor itu menggunakan diagram garis atau diagram batang. Penyebabnya adalah karena IPS2 tidak memahami dengan sesungguhnya perbedaan antara diagram batang dan diagram garis. Hal ini ditunjukkan pada jawaban yang diberikan IPS2 pada gambar 22 di atas, IPS2 menggambar kedua diagram tersebut, yaitu diagram batang dan diagram garis.

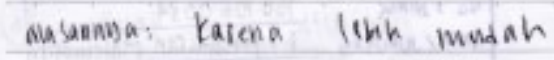

\section{Gambar 23 Pekerjaan IPS3 Indikator 3}

IPS3 memberikan jawaban bahwa diagram yang tepat adalah diagram garis seperti pada gambar 23 di atas. Akan tetapi, diagram garis yang dibuat oleh IPS3 tidak tepat. Selain itu, berdasarkan jawaban pada gambar 23 diketahui bahwa IPS3 tidak memahami filosofi penggunaan diagram garis, karena alasan yang dituliskan oleh IPS3 hanya karena lebih mudah.

c. SMK

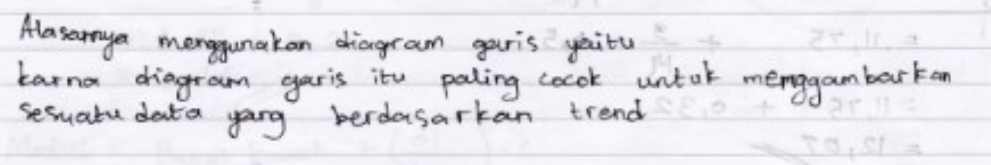

Gambar 24 Pekerjaan SMK1 Indikator 3

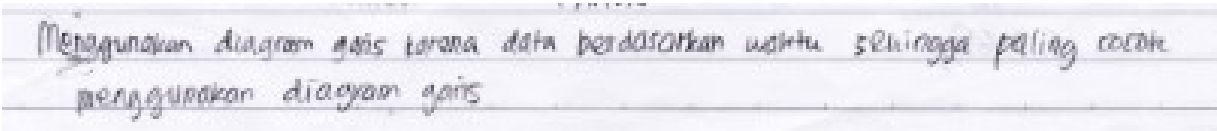

Gambar 25 Pekerjaan SMK2 Indikator 3

Berdasarkan gambar 24 dan 25 di atas, diketahui bahwa SMK1 dan SMK2 memberikan alasan mengapa diagram yang sesuai adalah diagram garis adalah data tersebut merupakan data berdasarkan waktu. Hal ini menunjukkan bahwa SMK1 dan SMK2 sudah mengarah pada jawaban yang tepat, akan tetapi kurang lengkap. SMK3 tidak menuliskan alasan mengapa menurutnya diagram batang merupakan diagram yang tepat untuk menengah mahasiswa program studi pendidikan matematika pada mata kuliah statistika deskriptif) 
menyajikan kembali data tentang penjualan sepeda motor dari tahun 2005 sampai tahun 2015 (gambar 9).

Berdasarkan deskripsi hasil pekerjaan mahasiswa di atas, maka kemampuan representasi matematis pada setiap indikatornya berdasarkan jenjang pendidikan disajikan dalam tabel 1. di bawah ini.

Tabel 1. Kemampuan Representasi Matematis Mahasiswa

\begin{tabular}{|c|c|c|c|}
\hline \multirow{2}{*}{$\begin{array}{c}\text { Indikator } \\
\text { Kemampua } \\
\text { n } \\
\text { Representasi } \\
\text { Matematis } \\
\end{array}$} & \multicolumn{3}{|c|}{ Peminatan } \\
\hline & SMA IPA & SMA IPS & SMK Teknik \\
\hline $\begin{array}{l}\text { Kemampuan } \\
\text { untuk } \\
\text { menyajikan } \\
\text { data atau } \\
\text { informasi } \\
\text { dari masalah } \\
\text { matematis ke } \\
\text { dalam bentuk } \\
\text { diagram, } \\
\text { grafik atau } \\
\text { tabel atau } \\
\text { sebaliknya. }\end{array}$ & $\begin{array}{lr}\text { Mampu menyajikan } \\
\text { kembali dalam grafik } \\
\text { yang tepat, yaitu diagram } \\
\text { garis, walaupun tidak } \\
\text { lengkap. Akan tetapi, } \\
\text { ketika ditanyakan } \\
\text { mereka dapat } \\
\text { mengoreksi kekurangan } \\
\text { pada diagram garis yang } \\
\text { mereka buat. } \\
\text { Ketidaklengkapan ini } \\
\text { dikarenakan, mahasiswa } \\
\text { kurang tenang ataupun } \\
\text { merasa kekurangan } \\
\text { waktu pengerjaannya. }\end{array}$ & $\begin{array}{l}\text { Mahasiswa } \\
\text { dengan jenjang } \\
\text { pendidikan IPS } \\
\text { saat sekolah } \\
\text { menengah atas } \\
\text { tidak mampu } \\
\text { menentukan } \\
\text { diagram yang } \\
\text { tepat untuk } \\
\text { menyajikan } \\
\text { kembali data. }\end{array}$ & $\begin{array}{l}\text { Berdasarkan } \\
\text { hasil pekerjaan } \\
\text { mahasiswa } \\
\text { dengan jenjang } \\
\text { pendidikan } \\
\text { SMK jurasn } \\
\text { teknik saat } \\
\text { sekolah } \\
\text { menengah atas } \\
\text { diketahui bahwa } \\
\text { mereka mampu } \\
\text { untuk } \\
\text { menyajikan } \\
\text { kembali data. } \\
\text { walaupun } \\
\text { kurang } \\
\text { lengkap. Akan } \\
\text { tetapi, hasil } \\
\text { wawancara } \\
\text { menunjukkan } \\
\text { bahwa } \\
\text { mahasiswa } \\
\text { tersebut hanya } \\
\text { mengikuti } \\
\text { contoh yang } \\
\text { pernah diberikan } \\
\text { oleh dosen saat } \\
\text { mengikuti } \\
\text { perkuliah. }\end{array}$ \\
\hline $\begin{array}{l}\text { Kemampuan } \\
\text { menggunaka } \\
\mathrm{n} \text { simbol } \\
\text { matematis } \\
\text { dengan tepat } \\
\text { dalam } \\
\text { penyelesaian } \\
\text { masalah } \\
\text { matematis. }\end{array}$ & $\begin{array}{l}\text { Mahasiswa sudah } \\
\text { mampu menggunakan } \\
\text { simbol dengan tepat } \\
\text { sesuai kaidah penulisan } \\
\text { dalam matematika saat } \\
\text { menyelesaikan masalah } \\
\text { matematis. }\end{array}$ & $\begin{array}{l}\text { Berdasarkan } \\
\text { jawaban } \\
\text { mahasiswa di } \\
\text { atas, dapat } \\
\text { disimpulkan } \\
\text { bahwa untuk } \\
\text { mahasiswa } \\
\text { dengan jenjang } \\
\text { pendidikan SMA } \\
\text { IPS tidak } \\
\text { mampu }\end{array}$ & $\begin{array}{l}\text { Mahasiswa yang } \\
\text { berasal dari } \\
\text { SMK teknik } \\
\text { mampu } \\
\text { menggunakan } \\
\text { simbol } \\
\text { matematis tepat, } \\
\text { walaupun masih } \\
\text { ada sedikit } \\
\text { kekurangan. }\end{array}$ \\
\hline
\end{tabular}




\begin{tabular}{|c|c|c|c|}
\hline \multirow{2}{*}{$\begin{array}{c}\text { Indikator } \\
\text { Kemampua } \\
\text { n } \\
\text { Representasi } \\
\text { Matematis }\end{array}$} & \multicolumn{3}{|c|}{ Peminatan } \\
\hline & SMA IPA & SMA IPS & SMK Teknik \\
\hline $\begin{array}{l}\text { Kemampuan } \\
\text { menuliskan } \\
\text { pendapat atau } \\
\text { alasan } \\
\text { dengan tepat. }\end{array}$ & $\begin{array}{l}\text { Secara umum mahasiswa } \\
\text { dengan peminatan IPA } \\
\text { dapat memahami makna } \\
\text { dari penggunaan diagram } \\
\text { atau grafik dan mampu } \\
\text { memberikan alasan yang } \\
\text { tepat. }\end{array}$ & $\begin{array}{l}\text { menggunakan } \\
\text { simbol matematis } \\
\text { dengan tepat saat } \\
\text { menyelasikan } \\
\text { masalah } \\
\text { matematis yang } \\
\text { diberikan. } \\
\text { Secara umum, } \\
\text { mahasiswa tidak } \\
\text { dengan } \\
\text { peminatan IPS } \\
\text { saat sekolah } \\
\text { menengah atas } \\
\text { tidak mampu } \\
\text { memberikan } \\
\text { alasan yang tepat } \\
\text { dari diagram } \\
\text { yang digunakan. }\end{array}$ & $\begin{array}{l}\text { Secara umum } \\
\text { mahasiswa } \\
\text { dengan jenjang } \\
\text { pendidikan } \\
\text { SMK teknik } \\
\text { pada sekolah } \\
\text { menengah atas } \\
\text { sudah } \\
\text { mengarah pada } \\
\text { alasan yang } \\
\text { tepat. Akan } \\
\text { tetapi, masih } \\
\text { kurang lengkap } \\
\text { dalam } \\
\text { memberikan } \\
\text { alasannya. }\end{array}$ \\
\hline
\end{tabular}

bahwa pada setiap indikator, baik indikator kemampuan untuk menyajikan data atau informasi dari masalah matematis ke dalam bentuk diagram, grafik atau tabel atau sebaliknya; kemampuan menggunakan simbol matematis dengan tepat dalam penyelesaian masalah matematis; ataupun indikator kemampuan menuliskan pendapat atau alasan dengan tepat, terlihat bahwa mahasiswa dengan latar belakang jurusan SMA IPA sudah mampu untuk menunjukkan indikator kemampuan representasi matematis. Jika dibandingkan, maka urutan kemampuan repersentasi untuk masingmasing indikator adalah SMA IPA, SMK Teknik, dan SMA IPS.

Perbedaan kemampuan pada setiap jenjang pendidikan sangat dipengaruhi oleh struktur kurikulum yang berlaku saat mahasiswa tersebut berada di sekolah menengah atas dan sederajat. Walaupun jumlah jam yang diberikan kepada mahasiswa dan kompetensi dasarnya baik jurusan SMA IPA, SMK Teknik, maupun SMA IPS sama, akan tetapi kedalaman materi yang diberikan berbeda-beda. Hal ini terkait dengan kebutuhan siswa tersebut kelak jika sudah lulus dari sekolah menengah atas. Bagi siswa SMA, setelah lulus mereka diarahkan untuk melanjutkan studi mereka ke pendidikan tinggi. Oleh sebab itu, kemampuan ini sangat dibutuhkan untuk menyelesaikan tugas mereka di pendidikan tinggi. Berbeda dengan siswa SMK, setelah mereka lulus, mereka diarahkan terampil dalam dunia kerja. Hal ini mengakibatkan fokus dalam pendidikan siswa SMK adalah keterampilan di dunia kerja. Walaupun tidak dipungkiri, kemampuan ini juga dibutuhkan.

Antara mahasiswa yang berasal dari SMA IPA dan SMA IPS juga terdapat perbedaan dalam kemampuan representasi matematis. Perbedaan ini dikarenakan, bagi siswa SMA dengan jurusan IPA lebih sering menggunakan kemampuan representasi dalam menyelasikan masalah-masalah matematis dibandingkan dengan siswa IPS, sehingga siswa dengan jurusan IPA mempunyai kesempatan yang lebih luas untuk mengasah kemampuan representasi matematis. Akibatnya, kemampuan representasi matematis siswa SMA jurusan IPA lebih baik dibandingkan siswa SMA 
jurusan IPS. Selain itu, perbedaan kemampuan ini juga dipengaruhi olem kemampuan berpikir mereka. Siswa SMA dengan jurusan IPA cenderung berpikir lebih sistematis dan terbiasa menggunakan simbol dibandingkan siswa jurusan IPS, sedangkan siswa IPS lebih banyak menggunakan kata-kata deskriptif untuk menyajikan suatu informasi.

\section{KESIMPULAN}

Berdasarkan hasil penelitian dan pembahasan, disimpulkan sebagai berikut.

1. Kemampuan untuk menyajikan data atau informasi dari masalah matematis ke dalam bentuk diagram, grafik atau tabel atau sebaliknya.

Untuk indikator ini dapat disimpulkan bahwa mahasiswa dengan latar belakang SMA IPA mampu menyajikan data atau informasi ke dalam bentuk diagram atau grafik yang sesuai, mahasiswa dengan latar belakang pendidikan SMA IPS tidak mampu menyajikan data atau informasi ke dalam bentuk diagram atau grafik yang sesuai, sedangkan mahasiswa dengan latar belakang SMK jurusan teknik sudah mampu menyajikan data atau informasi ke dalam bentuk diagram atau grafik yang sesuai, walaupun belum memahami secara mendalam makna dari setiap kegunaan diagram atau grafik.

2. Kemampuan menggunakan simbol matematis dengan tepat dalam penyelesaian masalah matematis.

Pada indikator ini disimpulkan bahwa mahasiswa dengan latar belakang SMA IPA mampu menggunakan simbol dengan tepat sesuai kaidah penulisan dalam matematika saat menyelesaikan masalah matematis, mahasiswa dengan latar belakang pendidikan SMA IPS tidak mampu menggunakan simbol dengan tepat saat menyelesaikan masalah matematis, sedangkan mahasiswa dengan latar belakang SMK jurusan teknik sudah mampu menggunakan simbol matematis dengan tepat, walaupun belum sempurna (masih ada sedikit kesalahan).

3. Kemampuan menuliskan pendapat atau alasan dengan tepat.

Pada indikator ini mahasiswa dengan latar belakang pendidikan SMA IPA mampu memberikan alasan yang tepat, mahasiswa dengan latar belakang pendidikan SMA IPS tidak mampu memberikan alasan yang tepat, sedangkan mahasiswa dengan latar belakang pendidikan SMK jurusan teknik sudah mengarah pada alasan yang tepat, akan tetapi masih ada kekurangan.

\section{DAFTAR PUSTAKA}

Hwang, W., Chen, N., Dung, J., Educational, Y. Y.-J. of, \& 2007, undefined. (2007). Multiple Representation Skills and Creativity Effects on Mathematical Problem Solving using a Multimedia Whiteboard System. Jstor, 10, 191-212. Retrieved from http://www.jstor.org/stable/jeductechsoci.10.2.191

Luitel, B. C. (2002). Representation of Mathematical learning: A short discourse. In 25th Conference Organised by Western Australian Science Education Association, Canning College., (November), 1999-2002.

Nurrakhmi, R. Z. F., \& Lukito, A. (2014). MATHE dunesa. Jurnal Ilmiah Pendidikan Matematika, 3(3), 208-214. Retrieved from http:/jurnalmahasiswa.unesa.ac.id/index.php/mathedunesa/article/view/12943/16729

Pawestri, E., \& Sukoco, H. (2017). Pengembangan Perangkat Pembelajaran Lembar Kerja Siswa Dengan Pendekatan Kontekstual Untuk Meningkatkan Kemampuan Pemecahan Masalah Siswa, 2(1), 69-76.

Reahanah. (2016). Efektifitas Model Pembelajaran Problem Solving Tipe Search Solve Create And 
Vol. 2, No. 2, April 2018, pp. 15-32

Share (Sscs) Dan Cooperative Problem Solving (Cps) Ditinjau Dari Kemampuan Matematis Terhadap Prestasi Belajar. Jurnal Pijar MIPA, XI(2), 1-22. https://doi.org/10.13040/IJPSR.0975-8232.6(2).688-91

Tipps, S., Johnson, A., \& Kennedy, L. M. (2011). Guiding Children's Learning of Mathematics. Cengage Learning. Retrieved from https://books.google.com.sg/books?id=LVDADyKMCasC

Widyastuti, R., \& Nurhamida, F. (2017). Metode Discovery Learning Berbantuan Software Geogebra Untuk Meningkatkan Kemampuan Berfikir Matematis Mahasiswa Politeknik Kediri Discovery Learning Method Through Geogebra Software To Improve Mathematical Thinking Ability Of Polytechnic Of Kediri Students, 2(1), 31-39. 